DOI: $10.15193 /$ zntj/2020/124/353

\author{
BEATA MIKUTA, IZABELA MIŁKOWSKA, NATALIA SOBCZYK, \\ ANITA SZCZECHOWICZ
}

\title{
OCENA SPOŻYCIA PODSTAWOWYCH SKŁADNIKÓW ODŻYWCZYCH PRZEZ OSOBY STARSZE Z POWIATU CZESTOCHOWSKIEGO
}

\author{
Streszczenie
}

Celem pracy była ocena spożycia podstawowych składników odżywczych oraz wybranych witamin z grupy B przez osoby starsze z powiatu częstochowskiego, na podstawie badań pilotażowych. Badaniem pilotażowym objęto 20 osób powyżej 65. roku życia. Do oceny sposobu żywienia zastosowano jednorazowo metodę 24-godzinnego wywiadu żywieniowego oraz analizę ilościową.

Dieta kobiet i mężczyzn była uboga w białko (83 i 84 \% realizacji normy) i węglowodany (87 i $89 \%$ realizacji normy). Kobiety spożywały prawidłowe ilości kwasów tłuszczowych $n-3$ (96\% realizacji normy) i cholesterolu (102\% realizacji normy), mężczyźni spożywali odpowiednie ilości energii, kwasów thuszczowych jednonienasyconych (95 i $93 \%$ realizacji normy). Obie grupy spożywały zbyt dużo kwasów tłuszczowych nasyconych (realizacja normy: kobiety - 128 \%, mężczyźni - $201 \%$ ), a mężczyźni dodatkowo deklarowali duże spożycie kwasów thuszczowych ogółem i cholesterolu (116 i $201 \%$ realizacji normy). Stwierdzono prawidłowe spożycie tiaminy $\left(\mathrm{B}_{1}\right)$ przez kobiety i mężczyzn, odpowiednio na poziomie 92 i $98 \%$ realizacji normy. W przypadku pozostałych witamin - ryboflawiny $\left(\mathrm{B}_{2}\right)$, niacyny $\left(\mathrm{B}_{3}\right)$ i pirydoksyny $\left(\mathrm{B}_{6}\right)$ odnotowano ich nadmierne spożycie. Wykazane błędy żywieniowe o charakterze ilościowym wskazują na nieprawidłowości w odżywianiu się badanej grupy seniorów, dlatego posłużą do zaplanowania i zrealizowania badań na reprezentatywnej grupie osób starszych, aby można było w pełni ocenić stan odżywienia tej populacji. Konieczna jest także edukacja żywieniowa seniorów oraz ich opiekunów.

Słowa kluczowe: osoby starsze, sposób żywienia, składniki odżywcze, składniki energetyczne, normy żywienia, ocena żywienia

\section{Wprowadzenie}

Od kilkunastu lat w Polsce obserwuje się proces zmian demograficznych, który odznacza się zwiększaniem odsetka osób w wieku starszym. Przewiduje się, że w 2035 r.

Dr inż. B. Mikuta, I. Miłkowska, N. Sobczyk, mgr A. Szczechowicz, Katedra Dietetyki i Badań Żywności, Wydz. Nauk Ścisłych, Przyrodniczych i Technicznych, Uniwersytet Humanistyczno-Przyrodniczy im. Jana Dlugosza w Czestochowie, al. Armii Krajowej 13/15, 42-200 Częstochowa.

Kontakt:b.mikuta@ujd.edu.pl 
w Polsce $23 \%$ ludności będą stanowiły osoby starsze, w tym liczba dziewięćdziesięciolatków wzrośnie 2,5-krotnie [15]. Starzenie to naturalny proces, ale zarazem nieuchronny i nieodwracalny [7]. Wraz z wiekiem dochodzi do zachwiania równowagi organizmu spowodowanego upośledzeniem ważnych funkcji fizjologicznych. Liczne zmiany, m.in. w układach: pokarmowym, krążenia, immunologicznym oraz w układzie oddechowym prowadzą do unikania potraw, które są trudne do zmetabolizowania, a dostarczają wielu cennych składników odżywczych, co w konsekwencji może przyczyniać się do niedoborów i w końcu do niedożywienia [18]. Seniorzy popełniają szereg błędów żywieniowych. Osoby starsze spożywają różnego rodzaju przekąski, używają zbyt dużej ilości soli, korzystają z żywności, która jest nadmiernie przetworzona, np. margaryny, ciastka. W diecie osób starszych brakuje warzyw, owoców, produktów zbożowych, ryb, napojów [6]. Ważne jest, aby dieta seniorów była odpowiednio dobrana, gdyż stosowanie się do zaleceń pomaga zmniejszać ryzyko chorób w procesie starzenia $[8,19]$.

Celem pracy była ocena spożycia składników podstawowych oraz wybranych witamin z grupy B przez osoby starsze z powiatu częstochowskiego, na podstawie badań pilotażowych.

\section{Material i metody badań}

Badaniem pilotażowym [4] objęto grupę 20 osób powyżej 65. roku życia. W badaniach sposobu żywienia zastosowano jednorazowo metodę 24-godzinnego wywiadu żywieniowego oraz analizę ilościową.

Narzędziem badawczym był autorski kwestionariusz wywiadu, który składał się z dwóch części - metryczki i informacji o posiłkach spożywanych w ciągu dnia. Kwestionariusz wywiadu był wypełniany samodzielnie przez badanych. Pytania metryczkowe dotyczyły płci, wieku, masy ciała, wzrostu, rodzaju aktywności fizycznej, miejsca zamieszkania, chorób metabolicznych. Zebrane w metryczce informacje pozwoliły na określenie BMI respondentów oraz ich zapotrzebowania na energię, składniki podstawowe i wybrane witaminy z wykorzystaniem „Norm żywienia dla populacji Polski” [7]. Następnie $\mathrm{z}$ równania na średnią ważoną obliczano zapotrzebowanie na energię, składniki podstawowe i witaminy z grupy B, osobno dla kobiet i osobno dla mężczyzn.

Informacje o spożywanych posiłkach badani wpisywali do tabeli kwestionariusza, podając rodzaj posiłku, produkty spożyte w ramach posiłku, wielkość w miarach przybliżonych. Uzyskane dane przeliczano na jednostki masowe (gramy) [9]. Następnie obliczano spożycie energii, składników podstawowych i wybranych witamin z grupy B. Szczególną uwagę zwracano na kwasy thuszczowe z podziałem na nasycone, jednonienasycone, wielonienasycone, kwasy tłuszczowe $n-3$ i $n-6$ oraz cholesterol. Do analizy ilościowej wybrano witaminy $\mathrm{z}$ grupy $\mathrm{B}$ : tiaminę $\left(\mathrm{B}_{1}\right)$, ryboflawinę $\left(\mathrm{B}_{2}\right)$, niacynę $\left(\mathrm{B}_{3}\right)$ i pirydoksynę $\left(\mathrm{B}_{6}\right)$, które uczestniczą w przemianach białek, thuszczów i węglo- 
wodanów [4]. Do obliczenia spożycia wybranych składników odżywczych posłużono się tabelami zamieszczonymi w opracowaniu „Wartość odżywcza wybranych produktów spożywczych i typowych potraw" [9]. Średnie spożycie składników odżywczych dla grupy kobiet i grupy mężczyzn porównano z obliczonym zapotrzebowaniem na składniki odżywcze dla badanej grupy na podstawie „Norm żywienia dla populacji Polski" [7].

Przy ocenie spożycia składników odżywczych dopuszczano odchylenie od normy $\mathrm{w}$ granicach $\pm 10 \%[5]$.

\section{Wyniki i dyskusja}

Badana grupa składała się z 10 kobiet i 10 mężczyzn, z czego $80 \%$ badanych należało do grupy wiekowej 65 - 74 lata, a $20 \%$ do grupy wiekowej powyżej 75 lat. Wszystkie osoby były mieszkańcami powiatu częstochowskiego i jako miejsce zamieszkania wskazały miasto. Ankietowani tworzyli gospodarstwa domowe z bliskimi. Prawidłową masę ciała (BMI w przedziale $18,5 \div 24,99$ ) miało zaledwie $35 \%$ badanych, natomiast $45 \%$ osób charakteryzowała nadwaga (BMI w przedziale $25,00 \div$ 29,99 ), a $20 \%$ - otyłość (BMI $\geq 30,00$ ). Ponadto $10 \%$ seniorów było zagrożonych niedożywieniem (BMI $<18,5)$. Co druga osoba miała zaburzenia lipidowe, natomiast $45 \%$ ankietowanych zmagało się z nadciśnieniem tętniczym, a $5 \%$ - z niedociśnieniem.

Po przeanalizowaniu spożycia wybranych składników odżywczych przez kobiety zaobserwowano prawidłowe spożycie kwasów tłuszczowych $n-3$ (2,04 g), cholesterolu $(205,4 \mathrm{mg})$ i witaminy $\mathrm{B}_{1}(1,01 \mathrm{mg})$. Kobiety spożywały duże ilości kwasów tłuszczowych nasyconych $(19,1 \mathrm{~g})$ i witaminy $\mathrm{B}_{3}(15,97 \mathrm{mg})$, w diecie było też dużo witamin $\mathrm{B}_{2}(1,67 \mathrm{mg})$ i $\mathrm{B}_{6}(2,24 \mathrm{mg})$. Mimo że $65 \%$ badanych seniorek wykazywało nadwagę lub otyłość, kobiety dostarczały $\mathrm{z}$ pożywieniem zbyt małych ilości energii (1582,3 kcal), białka (71,6 g), węglowodanów (216,9 g), kwasów tłuszczowych ogółem $(49,3 \mathrm{~g})$, a także kwasów tłuszczowych jednonienasyconych $(18,7 \mathrm{~g})$, wielonienasyconych (9,6 g), w tym kwasów n-6 (7,5 g) - tab. 1.

W przypadku mężczyzn odnotowano prawidłowe spożycie energii (2256,2 kcal), kwasów tłuszczowych jednonienasyconych $(36,8 \mathrm{~g})$ i witaminy $\mathrm{B}_{1}(1,28 \mathrm{mg})$. Do grupy składników o zbyt dużym spożyciu należały kwasy tłuszczowe ogółem $(91,8 \mathrm{~g})$, kwasy thuszczowe $n-3(2,99 \mathrm{~g})$, witaminy $\mathrm{B}_{3}(20,07 \mathrm{mg})$ i $\mathrm{B}_{6}(2,16 \mathrm{mg})$. Bardzo duże było u nich spożycie kwasów tłuszczowych nasyconych $(37,1 \mathrm{~g})$, cholesterolu $(437,8 \mathrm{mg})$ i ryboflawiny $(1,85 \mathrm{mg})$, natomiast zbyt małe spożycie - białka $(90 \mathrm{~g})$, węglowodanów (274,3 g), kwasów tłuszczowych wielonienasyconych $(16,5 \mathrm{~g})$, w tym $n-6(13,49 \mathrm{~g})-$ tab. 1. 
Tabela 1. Spożycie energii i wybranych składników odżywczych przez badaną grupę seniorów Table 1. Intake of energy and selected nutrients in the group of seniors surveyed

\begin{tabular}{|c|c|c|c|c|}
\hline \multirow[b]{2}{*}{$\begin{array}{l}\text { Energia i składniki odżywcze } \\
\text { Energy and nutrients }\end{array}$} & \multicolumn{2}{|c|}{ Kobiety / Women } & \multicolumn{2}{|c|}{ Mężczyźni / Men } \\
\hline & $\begin{array}{l}\text { Spożycie } \\
\text { Intake }\end{array}$ & $\begin{array}{c}\text { Norma } \\
\text { żywienia } \\
\text { Nutrition } \\
\text { standard }\end{array}$ & $\begin{array}{l}\text { Spożycie } \\
\text { Intake }\end{array}$ & $\begin{array}{c}\text { Norma } \\
\text { żywienia } \\
\text { Nutrition } \\
\text { standard }\end{array}$ \\
\hline Energia / Energy [kcal] & 1582,3 & 1920 & 2256,2 & 2380 \\
\hline Białko / Protein $[\mathrm{g}]$ & 71,6 & 86 & 90 & 107 \\
\hline Węglowodany / Carbohydrates [g] & 216,9 & 250 & 274,3 & 309 \\
\hline Kwasy tłuszczowe ogółem / Fatty acids [g] & 49,3 & 64 & 91,8 & 79 \\
\hline $\begin{array}{l}\text { Kwasy thuszczowe nasycone } \\
\text { Saturated fatty acids }[\mathrm{g}]\end{array}$ & 19,1 & 14,9 & 37,1 & 18,5 \\
\hline $\begin{array}{l}\text { Kwasy thuszczowe jednonienasycone } \\
\text { Monounsaturated fatty acids [g] }\end{array}$ & 18,7 & 32 & 36,8 & 39,7 \\
\hline $\begin{array}{l}\text { Kwasy thuszczowe wielonienasycone } \\
\text { Polyunsaturated fatty acids }[\mathrm{g}]\end{array}$ & 9,6 & 17,1 & 16,5 & 21,2 \\
\hline Kwasy tłuszczowe $n-3 / n-3$ fatty acids [g] & 2,04 & 2,13 & 2,99 & 2,64 \\
\hline Kwasy tłuszczowe $n-6 / n-6$ fatty acids [g] & 7,5 & 14,9 & 13,49 & 18,5 \\
\hline Cholesterol [mg] & 205,4 & 200 & 439,8 & 200 \\
\hline Tiamina $\left(\mathrm{B}_{1}\right) /$ Thiamine $\left(\mathrm{B}_{1}\right)[\mathrm{mg}]$ & 1,01 & 1,1 & 1,28 & 1,3 \\
\hline Ryboflawina $\left(\mathrm{B}_{2}\right)$ / Riboflavin $\left(\mathrm{B}_{2}\right)[\mathrm{mg}]$ & 1,67 & 1,1 & 1,85 & 1,3 \\
\hline Niacyna $\left(\mathrm{B}_{3}\right) / \operatorname{Niacin}\left(\mathrm{B}_{3}\right)[\mathrm{mg}]$ & 15,97 & 14 & 20,07 & 16 \\
\hline Pirydoksyna $\left(\mathrm{B}_{6}\right)$ / Pyridoxine $\left(\mathrm{B}_{6}\right)[\mathrm{mg}]$ & 2,24 & 1,5 & 2,16 & 1,7 \\
\hline
\end{tabular}

Jadłospisy respondentek charakteryzowały się średnio o $18 \%$ mniejszą podażą energii w stosunku do ustalonej normy, a jadłospisy badanych respondentów mieściły się w normie (rys. 1). Podobne wyniki w przypadku kobiet uzyskały Różańska i wsp. [10] w badaniach przeprowadzonych wśród mieszkańców Twardogóry. Dieta kobiet pokrywała $80 \%$ dziennego zapotrzebowania na energię, a mężczyzn - $77 \%$. Z kolei Markiewicz-Żukowska i wsp. [13] odnotowały wśród całej grupy pensjonariuszy jednego z Domów Pomocy Społecznej w Białymstoku zjawisko nadmiernej podaży energii w przypadku kobiet większe o $16 \div 64 \%$ w stosunku do wartości EER (ang. Estimated Energy Requirement), a mężczyzn - o $6 \div 41 \%$ w stosunku do tej wartości.

Stwierdzono, że realizacja zapotrzebowania na białko u kobiet wynosiła $83 \%$, a u mężczyzn - 84 \% (rys. 1). Białko jest istotnym składnikiem w diecie, gdyż w organizmie pełni przede wszystkim funkcję budulcową, jak również energetyczną, dlatego w diecie osób starszych powinno w $50 \%$ pochodzić z produktów pochodzenia zwierzęcego [16]. W badaniach przeprowadzonych przez Orkusz i Gorlę [14] zapotrzebowanie na białko było realizowane przez kobiety w przedziale $111,7 \div 119,9 \%$ normy, a przez mężczyzn w zakresie $99,3 \div 104,3 \%$, w zależności od pory roku. Pudełko 
i Nowak [16] w DPS na Śląsku stwierdziły, że kobiety realizowały zapotrzebowanie na białko w 144,84 \%, a mężczyźni w 127,28 \%. Znaczną nadpodaż białka odnotowała w badaniach Gacek [3] w okresie zimowym. W przypadku kobiet wynosiła ona 203,1 \% normy, a wśród mężczyzn - 188,6 \%. W badanej grupie spożycie białka w okresie letnim zmniejszyło się, ale nadal charakteryzowało się nadpodażą. Kobiety realizowały 180 \% normy na białko, a mężczyźni - 167 \%.

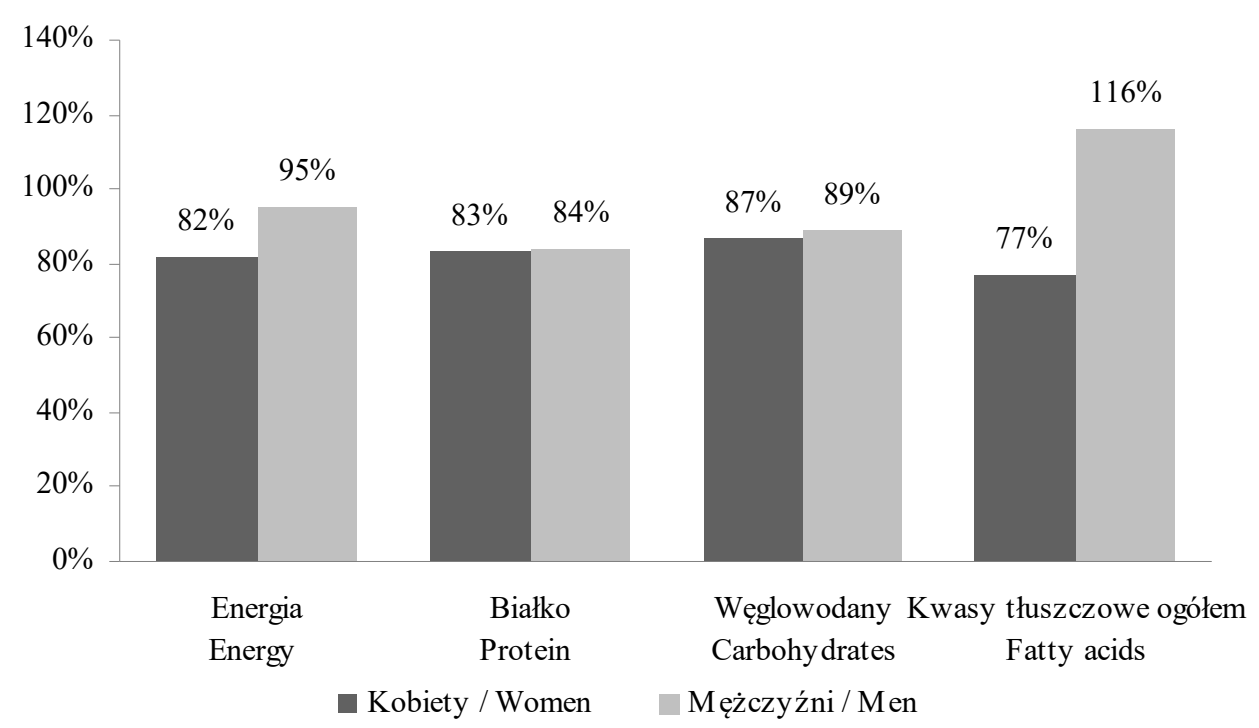

Rys. 1. Realizacja zapotrzebowania na energię i składniki energetyczne przez badaną grupę seniorów [\%]

Fig. 1. Meeting the energy and nutrient requirements in the group of seniors surveyed [\%]

W badaniach własnych spożycie węglowodanów przez kobiety było na poziomie $87 \%$ wartości normy, a mężczyzn - 89 \% (rys. 1). Zgodnie z zaleceniami [7] norma dla kobiet wynosi $250 \mathrm{~g}$. Węglowodany w diecie człowieka są najważniejszym i największym źródłem energii. W przypadku osób starszych składniki te powinny pochodzić z produktów zbożowych, warzyw, owoców oraz z nasion roślin strączkowych [16]. Niedostateczną podaż węglowodanów w żywieniu zaobserwowali Jurczak i wsp. [8] w badaniach osób starszych z Jodłowa i Nadziejowa oraz Różańska i wsp. [10] w ocenie żywienia seniorów z Twardogóry. Z kolei w badaniach przeprowadzonych w Domach Pomocy Społecznej na Śląsku Orkusz i Gorla [14] wykazały, że norma spożycia węglowodanów zarówno przez kobiety, jak i przez mężczyzn została zrealizowana w $284 \%$.

W jadłospisach seniorów z powiatu częstochowskiego wykazano nieprawidłowy udział energii pochodzącej $\mathrm{z}$ tłuszczów. $\mathrm{W}$ przypadku kobiet zapotrzebowanie na 
thuszcze zostało pokryte tylko w $77 \%$ normy, podczas gdy u mężczyzn zaobserwowano nadpodaż tego składnika, czyli $116 \%$ realizacji normy (rys. 1). Według norm żywienia [7] w diecie seniora powinno być $20 \div 35 \%$ tłuszczów. Po uwzględnieniu zmian fizjologicznych zachodzących w organizmie $\mathrm{z}$ wiekiem, a dodatkowo obciążenie większości respondentów chorobami układu krążenia bądź cukrzycą należy przyjąć, że z tłuszczów powinno pochodzić $30 \%$ energii. Pysz-Izdebska i wsp. [17] ocenili spożycie thuszczów przez kobiety w wieku podeszłym w jednym z Domów Pomocy Społecznej na terenie Krakowa i wykazali, że kobiety zrealizowały normę na tłuszcz w 105 \%. Różańska i wsp. [10] w badaniach mieszkańców Twardogóry stwierdziły natomiast udział tłuszczu w diecie seniorów na poziomie 33,5\%, czyli ponad $30 \%$, jednak w zakresie przewidzianym w normach żywienia [7].

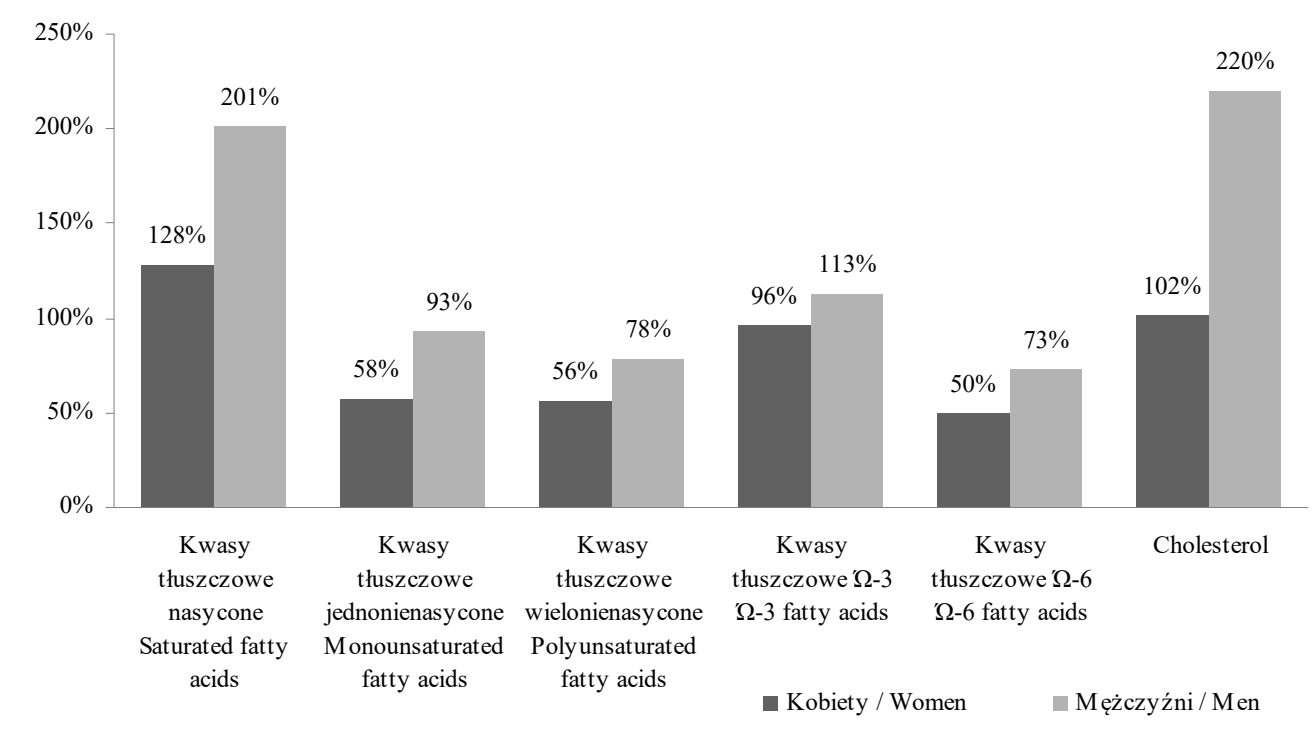

Rys. 2. Realizacja norm żywienia w zakresie składników tłuszczowych przez badaną grupę seniorów [\%]

Fig. 2. Meeting the requirements of nutrition standards as regards fat components in the group of seniors surveyed [\%]

Zarówno w przypadku kobiet, jak i mężczyzn odnotowano nieodpowiednią strukturę spożycia tłuszczów. Zbyt duży był udział energii pochodzącej z nasyconych kwasów tłuszczowych. Kobiety uzyskiwały średnio o $28 \%$ więcej energii pochodzącej z nasyconych kwasów tłuszczowych w stosunku do normy, natomiast mężczyźni przekraczali dzienne zapotrzebowanie średnio o ok. 100 \% (rys. 2). Zgodnie z rekomendacjami dotyczącymi leczenia dyslipidemii spożycie nasyconych kwasów tłuszczowych nie powinno przekraczać 7 \% dziennego zapotrzebowania [20]. Duże spożycie nasyco- 
nych kwasów tłuszczowych przez osoby starsze wykazano również $\mathrm{w}$ badaniach WOBASZ [18], przeprowadzonych w latach 2003 - 2005. Potwierdzono odbiegający od norm udział energii z kwasów tłuszczowych nasyconych, zarówno w jadłospisach kobiet, jak i mężczyzn (odpowiednio: 12,7 i 13,5 \%). W badaniach przeprowadzonych przez Markiewicz-Żukowską i wsp. [13] nie wykazano nadmiernie przekraczanej normy, szczególnie przez mężczyzn.

W niniejszej pracy realizację wartości normy na jednonienasycone kwasy thuszczowe odnotowano jedynie $\mathrm{w}$ jadłospisach mężczyzn i kształtowała się ona średnio na poziomie $93 \%$, podczas gdy kobiety zrealizowały tę normę zaledwie w $56 \%$ (rys. 2). Na podstawie informacji uzyskanych w jednym z Domów Pomocy Społecznej w Krakowie Pysz-Izdebska i wsp. [17] również zauważyli, w zależności od pory roku, brak pokrycia przyjętych zaleceń na jednonienasycone kwasy thuszczowe przez grupę respondentek (odpowiednio: 65,7 \% w okresie wiosennym i 68,2\% w okresie jesiennym). Mężczyźni zrealizowali zaś zapotrzebowanie na te kwasy w 73,6 \% wiosną i w $78,9 \%$ - jesienią.

Niezbędne nienasycone kwasy thuszczowe (NNKT) należą do grupy związków egzogennych [2]. Według Ciborowskiej i Rudnickiej [1] podaż wymienionych kwasów powinna wynosić $6 \div 10 \%$ dziennego zapotrzebowania. Zarówno kobiety, jak i mężczyźni nie zrealizowali tego zalecenia. Kobiety spożyły średnio 9,55 g NNKT, a mężczyźni - 16,48 g, co odpowiadało pokryciu wartości normatywnej odpowiednio: w 56 i $78 \%$ (rys. 2). Wyniki badań własnych były w tym zakresie zbliżone do oceny żywienia pensjonariuszy Domu Opieki w Białymstoku, przeprowadzonej przez Kołotę i wsp. [11].

Jadłospisy badanych respondentek charakteryzowały się prawidłową zawartością kwasów tłuszczowych $n$-3 (rys. 2). Pożądany stosunek kwasów tłuszczowych $n$-3 do $n$-6 powinien mieścić się w przedziale między $(1: 2) \div(1: 5)$ [1]. Różańska i wsp. [10] stwierdziły, że 91,4 \% mieszkanek Twardogóry nie spożywało zalecanej ilości kwasów thuszczowych $n-6$ i $n-3$. W badaniach własnych średnie spożycie kwasów $n$ - 3 w grupie mężczyzn okazało się nadmierne i wyniosło 113 \% normy (rys. 2). W badaniach PyszIzdebskiej i wsp. [17] wśród mężczyzn nie odnotowano znacznego przekraczania zalecanej normy na ten składnik.

W obu badanych grupach stwierdzono niewystarczające spożycie kwasów tłuszczowych $n-6$. Spożycie w grupie kobiet i mężczyzn było mniejsze odpowiednio: o 50 i $27 \%$ w stosunku do normy (rys. 2). Różańska i wsp. [10] także wcześniej podkreśliły niewystarczające spożycie tego składnika przez seniorów z Twardogóry.

Analiza jednodniowych jadłospisów respondentek dostarczyła informacji o zgodnej z przyjętymi zaleceniami podaży cholesterolu, która w badanej grupie kobiet wyniosła średnio 205,5 g, co stanowi 102,75 \% normy. Wśród mężczyzn odnotowano znaczną nadpodaż tego składnika wynoszącą średnio 439,8 mg/dobę, co stanowi 
219,9 \% normy (rys. 2). W obecnych „Normach żywienia dla populacji Polski” [7] nie podaje się dokładnych wytycznych spożycia cholesterolu. Według rekomendacji leczenia dyslipidemii spożycie cholesterolu przez osoby z zaburzeniami lipidowymi powinno się ograniczyć do $200 \mathrm{mg} /$ dobę [20]. Z uwagi na to, że autorzy innych badań przyjmowali znacznie wyższą normę na spożycie cholesterolu (do $300 \mathrm{mg} /$ dobę), interpretacja stopnia realizacji tego składnika może się różnić z wynikami niniejszej pracy. W badaniach oceny sposobu żywienia mieszkańców Twardogóry Różańska i wsp. [10] przedstawily dane, z których wynika, że zarówno mieszkanki, jak i mieszkańcy nie przekroczyli zalecanej ilości cholesterolu na dobę (odpowiednio: 210 i $253 \mathrm{mg}$ ).

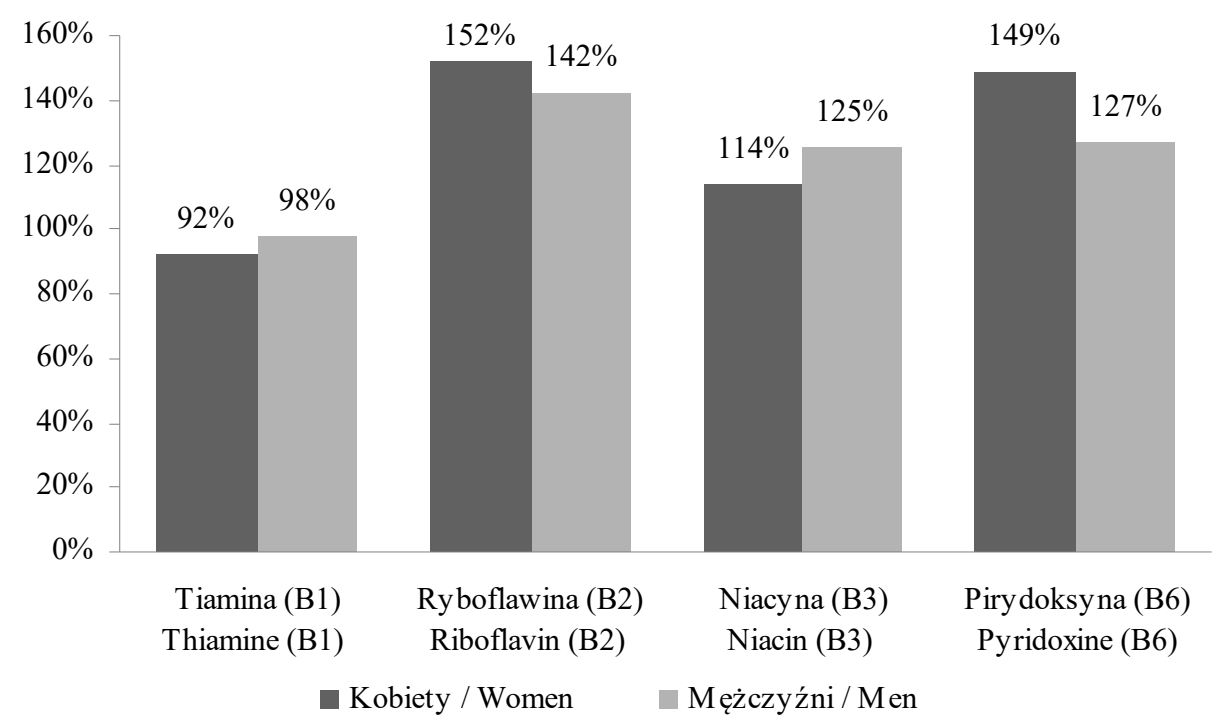

Rys. 3. Realizacja norm żywienia w zakresie wybranych witamin z grupy B przez badaną grupę seniorów [\%]

Fig. 3. Meeting the requirements of nutrition standards as regards selected B-group vitamins in the group of seniors surveyed [\%]

Spożycie witaminy $\mathrm{B}_{1} \mathrm{w}$ badanej grupie kobiet wyniosło 90,5 \% wartości normatywnej, a wśród mężczyzn - 99 \% (rys. 3). Zapotrzebowanie na tiaminę zgodnie z normą [7] wynosi $1,1 \mathrm{mg}$ dla kobiet i $1,3 \mathrm{mg}$ dla mężczyzn na dobę. W okresie starzenia pojawiają się problemy z koncentracją, dlatego ważne jest uzupełnianie diety w witaminę $\mathrm{B}_{1}$ [21]. Osoby starsze są częściej narażone na niedobór witaminy $\mathrm{B}_{1}$, jednak jej nadmiar nie jest szkodliwy, gdyż zbyt duża ilość spożytej tiaminy jest wydalana z moczem [21]. Wyniki badań własnych dotyczące kobiet korespondowały z oceną Malczyk i wsp. [12] przeprowadzoną z udziałem grupy osób starszych $z$ Jodłowa 
i Nadziejowa. Kobiety w wieku 66 - 75 lat realizowały spożycie witaminy $\mathrm{B}_{1}$ na poziomie $91 \%$ normy, natomiast respondentki powyżej 75. roku życia - w $81 \%$. Mężczyźni spożywali mniej witaminy $\mathrm{B}_{1}$ niż wykazano w badaniach własnych. Realizacja zapotrzebowania respondentów do 75 . roku życia na tę witaminę wyniosła $82 \%$ normy, powyżej 75 lat - $74 \%$ [12].

Spożycie witaminy $\mathrm{B}_{2}$ przez kobiety zostało zrealizowana w $151 \%$ normy, a przez mężczyzn - w 166,9 \% (rys. 3). Ryboflawina odgrywa ważną rolę w funkcjonowaniu układu nerwowego, poprawia wzrok, ma pozytywny wpływ na skórę i włosy, przyczynia się do niwelowania stanów zapalnych w jamie ustnej [21]. Zapotrzebowanie na tę witaminę dla kobiet wynosi $1,1 \mathrm{mg}$ na dobę. W badaniach prowadzonych wśród seniorów z Twardogóry Różańska i wsp. [10] stwierdziły poziom realizacji zapotrzebowania na witaminę $\mathrm{B}_{2}$ przez kobiety na poziomie $122,2 \%$, a przez mężczyzn $-109,1 \%$.

Poziom spożycia witaminy $\mathrm{B}_{3}$ został zrealizowany w grupie kobiet w $114 \%$ normy, a mężczyzn - w $125 \%$ (rys. 3). Zapotrzebowanie na witaminę $\mathrm{B}_{3}$ dla kobiet wynosi $14 \mathrm{mg}$, zaś dla mężczyzn $16 \mathrm{mg}$. Niacyna wspomaga układ nerwowy i wzmacnia odporność, która w starszym wieku jest osłabiona, dlatego ważna jest zbilansowana dieta [6, 21]. Nadpodaż nie wpływa na stan zdrowia [21]. Zbyt małe pokrycie zapotrzebowania na niacynę wśród kobiet odnotowali Kołot i wsp. [11]. Wyniki badań własnych odbiegają od analizy odżywiania się seniorów z Jodłowa i Nadziejowa. Malczyk i wsp. [12] wykazały bowiem, że kobiety w przedziale 66 - 75 lat pokrywały zapotrzebowanie na niacynę w $97 \%$, natomiast powyżej 75. roku życia realizacja była mniejsza i wynosiła $84 \%$ normy. Podobne wyniki otrzymano wśród mężczyzn, gdyż do 75 . roku życia zapotrzebowanie na witaminę $\mathrm{B}_{3}$ realizowali oni w $92 \%$, a w grupie powyżej 75 lat - w $82 \%$.

Średnie spożycie witaminy $\mathrm{B}_{6} \mathrm{w}$ badanej grupie kobiet przekraczało normę o niemal $50 \%$, a średnie zapotrzebowanie na pirydoksynę w grupie badanych mężczyzn zostało zrealizowane w 126,2 \% (rys. 3). Witamina $\mathrm{B}_{6}$ ma korzystny wpływ na układ nerwowy, krwiotwórczy, wzmacnia odporność, która z wiekiem się osłabia [21]. Norma na witaminę $\mathrm{B}_{6}$ wynosi $1,5 \mathrm{mg}$ dla kobiet i $1,7 \mathrm{mg}$ dla mężczyzn. Dla porównania - w badaniach przeprowadzonych wśród seniorów z Twardogóry poziom realizacji zapotrzebowania na pirydoksynę wynosił 107,7 \% wśród kobiet i 128,6 \% u mężczyzn [10].

W podjętych badaniach pilotażowych potwierdzono celowość analizowania i monitorowania sposobu żywienia osób starszych mieszkających w gospodarstwach domowych z rodziną, gdyż ta grupa jest opisywana w literaturze przedmiotu najrzadziej. Najczęściej badania sposobu żywienia są wykonywane wśród pensjonariuszy zamieszkujących Domy Pomocy Społecznej z uwagi na objęcie oceną większej populacji ankietowanych oraz możliwość wglądu w jadłospisy osób starszych. Wyniki badań wła- 
snych wskazują na nieprawidłowości w odżywianiu się badanej grupy seniorów, dlatego posłużą do zaplanowania i zrealizowania badań na reprezentatywnej grupie osób starszych, aby można było w pełni ocenić stan odżywienia tej populacji.

\section{Wnioski}

1. Dieta badanych seniorów nie spełniała norm przewidzianych dla tej grupy w zakresie spożycia energii, składników podstawowych oraz wybranych witamin $\mathrm{z}$ grupy $\mathrm{B}$.

2. Dieta kobiet i mężczyzn była uboga w białko (odpowiednio: 83 i $84 \%$ realizacji normy) i węglowodany (odpowiednio: 87 i $89 \%$ realizacji normy).

3. Obie grupy spożywały zbyt dużo kwasów tłuszczowych nasyconych (kobiety 128 \% realizacji normy, a mężczyźni - 201 \%). Mężczyźni dodatkowo deklarowali duże spożycie kwasów tłuszczowych ogółem i cholesterolu (116 i 201 \% realizacji normy).

4. Kobiety spożywały prawidłowe ilości kwasów tłuszczowych $n-3$ (96\% realizacji normy) i cholesterolu (102\%), mężczyźni zaś odpowiednie ilości energii i kwasów thuszczowych jednonienasyconych (95 i $93 \%$ realizacji normy).

5. Stwierdzono prawidłowe spożycie witaminy $\mathrm{B}_{1}$ przez kobiety i mężczyzn (odpowiednio: 92 i $98 \%$ realizacji normy). W przypadku pozostałych witamin: $\mathrm{B}_{2}, \mathrm{~B}_{3}$ i $\mathrm{B}_{6}$ odnotowano nadmierne ich spożycie przez obie grupy badanych.

6. Wykazane błędy żywieniowe o charakterze ilościowym wskazują na potrzebę monitorowania sposobu żywienia i edukację żywieniową seniorów oraz ich opiekunów.

\section{Literatura}

[1] Ciborowska H., Rudnicka A.: Dietetyka. Żywienie zdrowego i chorego człowieka. Wyd. Lek. PZWL, Warszawa 2018.

[2] Dawidziak J., Balcerkiewicz M.: Dieta jako uzupełnienie leczenia trądziku pospolitego (Acne vulgaris). Cz. II. Kwasy thuszczowe, indeks glikemiczny, przetwory mleczne. Farmacja Współczesna, 2016, 9, 67-72.

[3] Gacek M.: Zawartość energii i składników odżywczych w planowanych do spożycia racjach pokarmowych mieszkańców Domu Pomocy Społecznej w Krakowie. Rocz. PZH, 2010, 2, 207-212.

[4] Gawęcki J. (Red.): Żywienie człowieka. Podstawy nauki o żywieniu. Wyd. Nauk. PWN, Warszawa 2017.

[5] Grzymisławski M., Gawęcki J. (Red): Żywienie człowieka zdrowego i chorego. T. 2. Wyd. Nauk. PWN, Warszawa 2020.

[6] Jarosz E.: Dieta seniora. Wyd. Lek. PZWL, Warszawa 2019.

[7] Jarosz M. (Red.): Normy żywienia dla populacji Polski. Wyd. IŻŻ, Warszawa 2017.

[8] Jurczak I., Barylski M., Irzmański R.: Znaczenie diety u osób w wieku podeszłym - ważny aspekt prewencji zdrowia czy nieistotna codzienność? Gerontologia Polska, 2011, 5, 127-133. 
[9] Kunachowicz H., Nadolna I., Przygoda B.: Wartość odżywcza wybranych produktów spożywczych i typowych potraw. Wyd. Lek. PZWL, Warszawa 2014.

[10] Różańska D., Wyka J., Biernat J.: Sposób żywienia ludzi starszych mieszkających w małym mieście - Twardogórze. Probl. Hig. i Epidemiol., 2013, 94 (3), 494-502.

[11] Kołota A., Głąbska D., Włodarek D.: Analiza wartości odżywczej jadłospisów dekadowych starszych kobiet. Brom. Chemia Toksykol., 2016, 3, 536-540.

[12] Malczyk E., Zołoteńska-Synowiec M., Całyniuk B., Guzik W.: Ocena sposobu żywienia osób po 60. roku życia pochodzących z Jodłowa i Nadziejowa. Pielęg. Zdrowie Publ., 2014, 4 (3), 219-226.

[13] Markiewicz-Żukowska R., Naliwajko S.K., Karpińska E., Puścion-Jakubik A., Gromkowska-Kępka K.J., Soroczyńska J., Borawska M.H.: Wartość energetyczna i podaż podstawowych składników odżywczych w racjach pokarmowych zapewnianych seniorom przebywającym w Domu Pomocy Społecznej w Białymstoku. Probl. Higieny i Epidemiol., 2018, 99 (1), 52-57.

[14] Orkusz A., Gorla B.: Ocena sposobu żywienia mieszkańców Domu Pomocy Społecznej z terenu województwa dolnośląskiego. Nauki Inżynierskie i Technologie, 2016, 3(22), 51-62.

[15] Ożga E., Małgorzewicz S.: Ocena stanu odżywienia osób starszych. Geriatria, 2013, 7, 1-6.

[16] Pudełko A., Nowak J.: Analiza jadłospisów realizowanych w Domach Pomocy Społecznej zlokalizowanych na terenie województwa śląskiego w aspekcie zawartości makroskładników i wody. Gerontologia Polska, 2019, 27, 43-49.

[17] Pysz-Izdebska K., Leszczyńska T., Kopeć A., Nowacka E., Bugaj B.: Pokrycie zapotrzebowania na energię i wybrane składniki odżywcze w diecie pensjonariuszy Domu Pomocy Społecznej oraz ocena ich parametrów antropometrycznych. Żywność. Nauka. Technologia. Jakość., 2010, 6 (73), 239254.

[18] Sygnowska E., Waśkiewicz A.: Ocena sposobu żywienia osób w wieku 60-74 lat. Badanie Wobasz. Brom. Chemia Toksykol., 2011, 3, 240-244.

[19] Szmidt M., Granda D., Broda A., Brzozowska A.: Rola warzyw i owoców w diecie osób starszych. Kosmos 2019, 2 (323), 293-301.

[20] Szymański F.M., Barylski M., Cybulska B., Wożakowska-Kapłon B., Krasiński Z., Mamcarz A., Widecka K., Płatek A.E., Dudek D., Mickiewicz A., Kobayasi A., Dzida G., Grajek S., Wełnicki M., Zubilewicz T., Ufnal M., Hering D., Mizia-Stec K., Kasprzak J., Koziński M., Imiela J., Narkiewicz K., Gorczyca I., Postuła M., Jaguszewski M.J., Filipiak K.J.: Rekomendacje dotyczące leczenia dyslipidemii w Polsce - III Deklaracja Sopocka. Interdyscyplinarne stanowisko grupy ekspertów wsparte przez Sekcję Farmakoterapii Sercowo-Naczyniowej Polskiego Towarzystwa Kardiologicznego. Choroby Serca i Naczyń, 2018, 15 (4), 199-210.

[21] Włodarek D., Lange E., Kozłowska L., Głąbska D.: Dietoterapia. Wyd. Lek. PZWL, Warszawa 2020 .

\title{
ASSESSING INTAKE OF BASIC NUTRIENTS BY THE ELDERLY FROM CZĘSTOCHOWA DISTRICT
}

\author{
$\mathrm{S} u \mathrm{~mm}$ a r y
}

The objective of the survey research study was to assess, on the basis of a pilot survey research, the intake of basic nutrients and some selected B-group vitamins by the elderly from the Częstochowa district. The pilot survey included a group of 20 people aged 65 and over. To assess the diet of the elderly, a method of 24-hour dietary interview and a quantitative analysis were applied once. 
The diet of both the women and the men was low in protein ( 83 and $84 \%$ of RDA, viz. Recommended Daily Amount) and carbohydrates (87 and $89 \%$ of RDA). The women consumed proper amounts of $n-3$ fatty acids (96\% of RDA) and cholesterol (102\% of RDA), while the men consumed proper amounts of energy and monounsaturated fatty acids ( $95 \%$ and $93 \%$ of RDA). The two groups consumed too high amounts of saturated fatty acids (women $-128 \%$ of RDA, men $-201 \%$ of RDA); additionally the men declared to consume high amounts of total fatty acids and cholesterol (116\% and $201 \%$ of RDA). It was found that both the men and the women consumed proper amounts of thiamine $\left(\mathrm{B}_{1}\right)$, i.e. $92 \%$ and $98 \%$ of RDA, respectively. In the case of other vitamins, viz. riboflavin $\left(\mathrm{B}_{2}\right)$, niacin $\left(\mathrm{B}_{3}\right)$ and pyridoxine $\left(\mathrm{B}_{6}\right)$, an excessive intake thereof was reported. The identified dietary errors are quantitative in nature and show abnormalities in the diet of the group of seniors surveyed, thus they will be applied as a basis for the planning and conducting of a survey research on a representative group of the elderly in order to fully access the nutritional status of this population group. Also it is essential to educate seniors and their caregivers on the proper nutrition and diet.

Key words: the elderly, nutrition method, nutrients, energetic components, nutrition standards, assessment of nutrition 